\title{
Capsule Commentary on Gerber et al., Hormone Therapy Use in Women Veterans Accessing Veterans Health Administration Care: A National Cross-Sectional Study
}

\author{
E. Bimla Schwarz, MD, MS \\ University of California, Davis, Sacramento, CA, USA. \\ J Gen Intern Med 30(2):237 \\ DOI: $10.1007 / \mathrm{s} 11606-014-3093-5$ \\ (c) Society of General Internal Medicine 2014
}

$\mathrm{O}$ ver the past 20 years, the Women Veterans Health Care group has rolled out numerous initiatives designed to improve access and quality of care for the rapidly growing population of women veterans, ${ }^{1}$ guided by the vision that if "you served, you deserve the best care anywhere." Since 2008, the Veterans Administration (VA) "mini-residency" program has trained over 1,850 primary care providers in women's health care, with the goal of offering comprehensive primary care for women at all VA sites. VA rates of screening for cervical and breast cancer are now higher than those reported in most private sector settings, ${ }^{2}$ as are gender-neutral measures of quality care such as screening for colorectal cancer and management of hypertension, hyperlipidemia, and diabetes. ${ }^{2}$ However, our nation's solemn obligation "to care for [all those] who shall have borne the battle" remains a challenge and a focus of coast-to-coast attention.

In this paper by Gerber et al., women veterans are found to be receiving post-menopausal hormone therapy at twice the rate of civilian populations. ${ }^{3}$ This is a potentially concerning finding, given that such therapy increases women's risk of both cardiovascular disease and breast cancer. ${ }^{4}$ However, menopausal symptoms can be extremely distressing to women; when these symptoms are unresponsive to other therapies, many well-informed women and their physicians feel that the risks of hormone therapy are worth the relief it offers. Thus, before we can conclude that efforts are needed to reduce women veteran's use of post-menopausal hormone therapy, we need to know whether (and if so, why) women veterans are experiencing more distressing menopausal symptoms. For

example, as noted by Gerber et al., the prevalence of obesity, hysterectomy, history of trauma, and persistent anxiety (each of which exacerbate the vasomotor symptoms of menopause) are all higher among women veterans than other women. As such, although confirming that prescriptions are clinically indicated is a priority in ensuring that our veterans receive the high-quality care they deserve, disciplined identification of the root causes of symptoms and a commitment to informed decision-making regarding the full range of available treatments are equally necessary.

Conflict of Interest: The author has no conflicts of interest with regard to any of the material in this manuscript.

Corresponding Author: E. Bimla Schwarz, MD, MS; University of California, Davis, Sacramento, CA 95616, USA (e-mail: ebschwarz@ucdavis.edu).

\section{REFERENCES}

1. Frayne SM, Phibbs CS, Saechao F, Maisel NC, Friedman SA, Finlay A, Berg E, Balasubramanian V, Dally SK, Ananth L, Romodan Y, Lee J, Iqbal S, Hayes PM, Zephyrin L, Whitehead A, Torgal A, Katon JG, Haskell S. Sourcebook: Women Veterans in the Veterans Health Administration. Volume 3. Sociodemographics, Utilization, Costs of Care, and Health Profile. Washington DC: Women's Health Evaluation Initiative, Women's Health Services, Veterans Health Administration, Department of Veterans Affairs; 2014. Available online at http://www.womenshealth.va.gov/ WOMENSHEALTH/docs/Sourcebook_Vol_3_FINAL.pdf. Accessed October $23,2014$.

2. VHA Facility Quality and Safety Report Fiscal Year 2012 Data. December 2013. Available online at http://www.va.gov/HEALTH/docs/ VHA_Quality_and_Safety_Report_2013.pdf. Accessed October 23, 2014.

3. Gerber MR, King MW, Pineles S, Wiltsey-Sturman S, Bean-Mayberry B, Japuntich S, Haskell S. Hormone therapy use in women veterans accessing Veterans Health Administration care: a national cross-sectional study. J Gen Intern Med. 2014. doi:10.1007/s11606-014-3073-9.

4. Rossouw JE, Anderson GL, Prentice RL, et al. Risks and benefits of estrogen plus progestin in healthy postmenopausal women: principal results From the Women's Health Initiative randomized controlled trial. JAMA J Am Med Assoc. 2002;288(3):321-333.

Published online November 12, 2014 